\title{
Interleukin-10 Gene-Modified Dendritic Cell-Induced Type 1 Regulatory T Cells Induce Transplant-Tolerance and Impede Graft Versus Host Disease After Allogeneic Stem Cell Transplantation
}

\author{
Jiangbo Wan Fang Huang Siguo Hao Weiwei Hu Chuanxu Liu \\ Wenhao Zhang Xiaohui Deng Linjun Chen Liyuan Ma Rong Tao \\ Department of Hematology, Xinhua Hospital affiliated with Shanghai Jiao Tong University School of \\ Medicine, Shanghai, China
}

\section{Key Words}

Interleukin (IL)-10 • Dendritic cells (DCs) • Type $1 \mathrm{~T}$ regulatory (Tr1) cells • Immune tolerance • Graft versus host disease (GVHD)

\begin{abstract}
Background/Aims: $\operatorname{Tr} 1$ cells can induce peripheral tolerance to self- and foreign antigens, and have been developed as a therapeutic tool for the induction of tolerance to transplanted tissue. We explored the feasibility of generating Tr1 cells by using IL-10 gene-modified recipient DCs $\left(D C_{\mathrm{LV}-\mathrm{IL}-10}\right)$ to stimulate donor naive $\mathrm{CD} 4^{+} \mathrm{T}$ cells. We also investigated some biological properties of Tr1 cells. Methods: $\mathrm{DC}_{\mathrm{LV}-\mathrm{IL}-10}$ were generated through DCs transduced with a lentivirus vector carrying the IL-10 gene, and $\operatorname{Tr} 1$ cells were produced by using $\mathrm{DC}_{\mathrm{LV}-\mathrm{IL}-10}$ to stimulate naive $\mathrm{CD} 4^{+} \mathrm{T}$ cells. The effects of $\operatorname{Tr} 1$ cells on $\mathrm{T}$-cell proliferation and the occurrence of graft versus host disease (GVHD) following allogeneic stem-cell transplantation (allo-HSCT) were investigated. Results: The $\mathrm{DC}_{\mathrm{LV}-\mathrm{IL}-10}$-induced Tr1 cells co-expressed LAG-3 and CD49b. Moreover, they also expressed CD4, CD25, and IL-10, but not Foxp3, and secreted significantly higher levels of IL-10 $(1,729.36 \pm 185.79 \mathrm{pg} / \mathrm{mL} ; P<0.001)$ and INF- $\gamma(1,524.48 \pm 168.65$ $\mathrm{pg} / \mathrm{mL} ; P<0.01$ ) than the control T cells upon the stimulation by allogeneic DCs. Tr1 cells markedly suppressed T-lymphocyte proliferation and the mixed lymphocytic response (MLR) in vitro. The mice used in the allo-HSCT model had longer survival times and lower clinical and pathological GVHD scores than the control mice. Conclusion: IL-10 gene-modified DCinduced $\operatorname{Tr} 1$ cells may be used as a potent cellular therapy for the prevention of GVHD after allo-HSCT.
\end{abstract}




\section{Cellular Physiology Cell Physiol Biochem 2017;43:353-366 \\ \begin{tabular}{ll|l} 
DOI: 10.1159/000480415 & O 2017 The Author(s). Published by S. Karger AG, Basel \\
www.karger.com/cpb
\end{tabular}}

Wan et al.: Type $1 \mathrm{~T}$ Regulatory Cells Induce Transplant-Tolerance

\section{Introduction}

T regulatory cells (Tregs) play a crucial role in the induction of peripheral tolerance to self- and foreign antigens. Numerous studies have demonstrated that Tregs are involved in the immunological dysregulation that underlies autoimmune diseases, chronic inflammatory diseases, and certain immunological complications of transplantation. Tregs are known to suppress the proliferation and effector functions of several different cell types, including $\mathrm{T}$ cells, B cells, natural killer (NK) cells, and antigen (Ag)-presenting cells (APCs) [1]. Tregs are also involved in immune homeostasis, regulation of inflammation, establishment and maintenance of immune tolerance, and prevention of graft versus host disease (GVHD) following an allogeneic hematopoietic stem cell transplant (allo-HSCT) [2, 3]. Tregs are divided into two categories: i) natural Tregs (nTregs), derived from the thymus and ii) adaptive or induced Tregs (aTregs or iTregs) induced outside the thymus in the presence of an antigen $(\mathrm{Ag})$ and tolerogenic conditions. Tr1 cells comprise the main subset of Tregs.

The nTregs constitutively express CD4, CD25 and Foxp3, protect self-tolerance, and prevent autoimmunity [4]. However, the paucity of nTregs tends to impede investigations into their applications in both animal models and clinical studies. There are also some obstacles to expanding nTregs in vitro. First, other types of T cells expand preferentially in culture [5]. Second, the immunosuppressive function of nTregs is not Ag-specific [6], and high nTreg to effector $\mathrm{CD}^{+} \mathrm{T}$ cell ratios (usually > 1:1) are needed to prevent GVHD [7]. In some cases, the large number of nTregs required to prevent GVHD can be impossible to achieved in humans [8]. Third, human nTregs often display unstable inhibitory activity in an ex-vivo environment, which makes them unsuitable for use in some preclinical models [9].

In contrast to nTregs, $\operatorname{Tr} 1$ cells specifically co-express CD 49b and LAG-3 [10]. Moreover, they also express CD4 and CD25, but not Foxp3. Upon activation, $\operatorname{Tr} 1$ cells modulate immune suppression mainly by secreting high levels of interleukin (IL)-10 and transforming growth factor (TGF)- $\beta$ [11-13]. A previous study showed that $\operatorname{Tr} 1$ cells can mediate immune suppression by killing antigen presenting cells (APCs) via a perforin/granzyme-dependent process that requires major histocompatibility complex (MHC) class I recognition [14]. Because $\operatorname{Tr} 1$ cells provide tolerance to foreign antigens, they also play an important role in organ transplantation.

Many protocols for the in vitro induction of $\operatorname{Tr} 1$ cells describe a process in which the $\operatorname{Tr} 1$ cells are induced in the presence of either recombinant IL-10 and IFN- $\gamma$ [15] or recombinant TGF- $\beta$ and IL-27 [16]. Tr1 cells can also be generated by a single stimulation with IL-10treated tolerogenic DCs [17]. However, only a minority of the $\operatorname{Tr} 1$ cells generated with most protocols produce IL-10. The main impediment to obtaining Tr1 cells for use in clinical applications such as cell therapy is the presence of contaminating effector T-cells in the resulting cell population. As an alternative method for obtaining a large and homogeneous population of $\operatorname{Tr} 1$ cells, lentivirus-mediated human $I L-10$ gene transfer has been used to convert conventional T cells into Tr1-like cells, which mirror the phenotype and function of Tr1 cells, and can suppress or prevent transplant rejection and GVHD. However, an important limitation of this method is that the generated Tr1-like cells cannot acquire autoantigen specificity [18].

We previously induced $\operatorname{Tr} 1$ cells by stimulating transgenic OT II mouse-derived naive $\mathrm{CD}^{+} \mathrm{T}$ cells with IL-10-expressing adenovirus ( $\left.\mathrm{AdV}_{\mathrm{IL}-10}\right)$-transfected and ovalbumin (OVA)pulsed dendritic cells $\left(\mathrm{DC}_{\mathrm{OVA} / \mathrm{L}-10}\right)$. That study demonstrated that both in vitro and in vivo, $\mathrm{DC}_{\text {oVA/L- }-10}$-stimulated CD4+ Tr1 cells acquired OVA peptide MHC class I (pMHC I), which targeted the suppressive effect of $\mathrm{CD}^{+} \operatorname{Tr} 1$ cells [12]. This targeting led to an $\sim 700 \%$ enhancement in the suppression of $\mathrm{DC}_{\mathrm{OVA}}$-induced $\mathrm{CD}^{+} \mathrm{T}$ cell responses and the immune response against OVA-expressing murine B16 melanoma cells, when compared with the responses shown by analogous $\mathrm{CD} 4^{+} \mathrm{Tr} 1$ cells without acquired pMHC I [12].

Therefore, we hypothesized that Tr1 cells could be generated through $I L-10$ genemodified recipient DCs by stimulating donor naive $\mathrm{CD} 4^{+} \mathrm{T}$ cells. Moreover, we also hypothesized that the presence of recipient pMHC I on $\operatorname{Tr} 1$ cells should enhance their 
Wan et al.: Type 1 T Regulatory Cells Induce Transplant-Tolerance

suppressive effect towards recipient cells. If so, an infusion of these $\operatorname{Tr} 1$ cells might induce transplant tolerance and prevent GVHD after allogeneic transplantation. In this study, we designed an experiment to explore the feasibility of using $I L-10$ gene-modified DCs to induce and expand Tr1 cells in vitro. We also assessed the immunosuppressive effects of the newly expanded Tr1 cells both in vitro and in vivo. Indeed, for the first time, we investigated the effects of in vitro-generated Tr1 cells on the incidence and severity of GVHD after an alloHSCT. Our data suggest that Tr1 cells generated with $I L-10$ gene-modified DCs can effectively inhibit $\mathrm{T}$ cell proliferation and the mixed lymphocyte reaction (MLR) in vitro, and also reduce the occurrence of GVHD in mice after a transplant.

\section{Materials and Methods}

\section{Animal studies}

C57BL/6 (H-2kb) and BALB/c (H-2kd) mice (age, 8-10 weeks) were purchased from Slac Laboratory Animal Co, Ltd. (Shanghai, China), and housed under specific pathogen-free conditions. All animal experiments were conducted according to guidelines published by The Ethics Committee of Xinhua Hospital Affiliated with the Shanghai Jiao Tong University School of Medicine. The protocols used in this study were approved by the Ethics Committee of Xinhua Hospital affiliated with Shanghai Jiao Tong University School of Medicine, Shanghai China.

\section{Cell culture and reagents}

RPMI-1640 medium, fetal bovine serum (FBS), recombinant mouse granulocyte- macrophage colonystimulating factor (rmGM-CSF), recombinant mouse interleukin (rmIL)-4 and rmIL-2 were purchased from PeproTech (PeproTech; Shanghai, China).

\section{Lentiviral IL-10 vector construction and transduction into dendritic cells}

The murine $I L-10$ gene was amplified by the polymerase chain reaction (PCR) performed with the following primers: forward: 5'-ACACCTCGAGATGCCTGGCTCAGCACTGC-3' and reverse: $5^{\prime}$-ATTAG CGGCCGCTTATTTGTCGTCATCATCCTT-3'. The purified $I L-10$ gene fragment was cloned into the pHBLV-CMVIRES-ZS Green plasmid (Hanbio Co., Ltd; Shanghai, China) using XhoI and NotI restriction sites. Lipofilter ${ }^{\mathrm{TM}}$ (Hanbio; Shanghai, China) was used to co-transfect the recombinant plasmid containing the $I L-10$ gene and green fluorescent protein (GFP) gene into 293T cells with a packaging plasmid (pSPAX2) and pMD2G envelop plasmid. Next, the virus particles were harvested from the cell supernatant and designated as LV-IL-10. Additionally, a control vector expressing GFP was constructed and designated as LV-GFP.

Bone marrow (BM)-derived DCs were generated as previously described [12]. Briefly, BM cells were isolated from the femora and tibiae of normal BALB/c mice, and the red blood cells were removed with $0.84 \%$ ammonium chloride. The remaining cells were plated using RPMI-1640 medium containing $10 \%$ FBS, $20 \mathrm{ng} / \mathrm{mL} \mathrm{rmGM-CSF}$, and $20 \mathrm{ng} / \mathrm{mL}$ rmIL-4 (Day 0). On day 3, the non-adherent granulocytes and $\mathrm{T}$ and B cells were gently dislodged and fresh medium was added. On day 5 , the loosely adherent proliferating DC aggregates were removed and re-plated using the previously described culture medium containing $1 \mu \mathrm{g} /$ mL lipopolysaccharides (LPS) (Sigma; Shanghai, China) and cultured until day 6, when the non-adherent DCs were collected. The collected DCs were then transduced with LV-GFP or LV-IL-10 overnight at $37^{\circ} \mathrm{C}$ with a multiplicity of infection of 100. GFP expression in the transduced DCs was detected by fluorescence microscopy at 24 hours after transduction, and the GFP-positive cells were sorted by flow cytometry. The purified GFP-positive DCs transduced with LV-GFP or LV-IL-10 were designated as $\mathrm{DC}_{\mathrm{GFP}}$ or DC $_{\mathrm{LV}-\mathrm{LL}-10^{\prime}}$ respectively.

Preparation of $D C_{L V-L L-10}$-induced Tr1 cells

Naive $\mathrm{CD} 4^{+} \mathrm{T}$ cells were isolated from the spleens of C57BL/6 mice using a Mouse Naive CD4+ $\mathrm{T}$ Cell Isolation Kit (StemCell Technologies; Shanghai, China) according to the manufacturer's protocol. The purity of the isolated naive $\mathrm{CD} 4^{+} \mathrm{T}$ cell populations routinely exceeded $98 \%$. For the generation of $\operatorname{Tr} 1$ cells, naive $\mathrm{CD}^{+} \mathrm{T}$ cells $\left(2 \times 10^{5}\right.$ cells $\left./ \mathrm{mL}\right)$ were stimulated for 3 days with irradiated (40 Gy) BM-derived DCs, DC or $\mathrm{DC}_{\mathrm{LV}-\mathrm{LL}-10}\left(1 \times 10^{5}\right.$ cells $\left./ \mathrm{mL}\right)$, respectively, in the presence of $20 \mathrm{U} / \mathrm{mL}$ rmIL-2, and then purified using a 


\section{Cellular Physiology Cell Physiol Biochem 2017;43:353-366

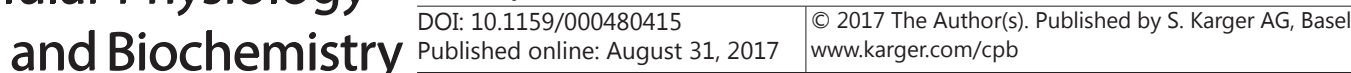

Wan et al.: Type 1 T Regulatory Cells Induce Transplant-Tolerance

Mouse $\mathrm{CD} 4^{+} \mathrm{T}$ cell Selection Kit (StemCell Technologies; Shanghai, China). The purified CD4 ${ }^{+} \mathrm{T}$ cells were designated as $\mathrm{T}_{\mathrm{DC}}{ }^{\prime} \mathrm{T}_{\mathrm{GPP}}$ or $\operatorname{Tr} 1$ cells.

\section{Flow cytometry}

Expression of CD11c and CD83 on DC $\mathrm{GFP}_{\text {and }}$ DC $\mathrm{LV}_{\mathrm{LV} \mathrm{L}-10^{\prime}}$ and expression of CD49b, LAG3, CD4, CD25, Foxp3 and IL-10 on $\mathrm{T}_{\mathrm{DC}}, \mathrm{T}_{\mathrm{GFP}}$ or Tr1 cells were detected by flow cytometry. Staining for CD11c, CD83, CD49b, LAG3, CD4, and CD25 on the cell surface was accomplished by incubating individual aliquots of cells on ice with fluorochrome-conjugated antibodies (eBioscience; Shanghai, China) for $30 \mathrm{~min}$. For intracellular staining of Foxp3, Tr1 cells were fixed and permeabilized, and then stained with FITC-conjugated antiFoxp3 monoclonal antibodies (eBioscience; Shanghai, China). For assays of the intracellular cytokines IL-10, Tr1 cells were treated with Cell Stimulation Cocktail $(2 \mu \mathrm{L} / \mathrm{mL})$ for $5 \mathrm{~h}$ at $37^{\circ} \mathrm{C}$ in the presence of $2 \mu \mathrm{L} / \mathrm{mL}$ Protein Transport Inhibitor Cocktail, and then permeabilized prior to staining with fluorescent dye-labeled anti-cytokine antibodies (eBioscience; Shanghai, China). Fluorescence-activated cell sorting (FACS) analyses for detection of various cell markers and cytokines were performed with a BD Canto II flow cytometer (Becton-Dickinson Biosciences, Shanghai, China).

\section{RNA isolation and real-time PCR}

To examine the levels of IL-10 mRNA expression in $\mathrm{DC}_{\mathrm{LV}-\mathrm{LL}-10}$, total RNA was extracted from DCs, $\mathrm{DC}_{\mathrm{GPP}}$ and $\mathrm{DC}_{\mathrm{LV}-\mathrm{L}-10}$ using TRIzol reagent (Takara; Liaoning, China); after which, a PrimeScript RT Master Mix kit (Takara Liaoning, China) was used to reverse transcribe $1 \mu \mathrm{g}$ of total RNA into cDNA. Real-time PCR array analysis was performed with a SYBR Premix Ex TaqTM Kit (Takara; Liaoning, China) in a total volume of $20 \mu \mathrm{L}$. Each reaction mixture contained $2 \mu \mathrm{L}$ of cDNA primers $(0.2 \mathrm{mM}$ each), $10 \mu \mathrm{L}$ of SYBR Green, and $0.4 \mu \mathrm{L}$ of Rox Dye II. The PCR conditions were $95^{\circ} \mathrm{C}$ for $30 \mathrm{~s}$, followed by 40 cycles of $95^{\circ} \mathrm{C}$ for $5 \mathrm{~s}$ and $60^{\circ} \mathrm{C}$ for $34 \mathrm{~s}$, with a final dissociation stage. The PCR samples were then analyzed using an ABI 7500 detector (Applied Biosystems; Foster City, CA, USA). The numbers of target genes were determined and normalized to the amount of GAPDH cDNA, which served as an internal standard (Sangon Biotech; Shanghai, China). The primers used for IL-10 were: forward: 5-GGACAACATACTGCTAACCGACTC-3 and reverse: 5-TGGGGCATCACTTCTACC-3 (Sangon Biotech; Shanghai, China).

\section{ELISA}

To detect IL-10, IL-6, TNF- $\alpha$, and IL-12p70 levels in the DCs, $\mathrm{DC}_{\mathrm{GFP}}$ and $\mathrm{DC}_{\mathrm{LL}-\mathrm{LL}-10^{\prime}}$ these cells were adjusted to concentrations $1 \times 10^{6}$ cells $/ \mathrm{mL}$ and activated with $200 \mathrm{ng} / \mathrm{mL}$ of LPS plus $50 \mathrm{ng} / \mathrm{mL}$ of rmIFN- $\gamma$ (Sigma; Shanghai, China) for $48 \mathrm{~h}$. The supernatants were then collected for analysis. The levels of IL-10, IL-6, TNF- $\alpha$, and IL-12p70 were measured with an ELISA kit (R\&D Systems; Shanghai, China) according to the manufacturer's instructions.

To detect IL-10, INF- $\gamma$, IL-2, and IL-4 secreted by $\mathrm{T}_{\mathrm{DC}}, \mathrm{T}_{\mathrm{GFP}}$ and $\mathrm{Tr} 1$ cells, these cells $\left(1 \times 10^{6}\right.$ cells/well $)$ were stimulated with irradiated (40 Gy) BM-derived DCs $\left(5 \times 10^{5}\right.$ cells/well) obtained from BALB/c mice for $48 \mathrm{~h}$. Next, the supernatants were harvested and the levels of IL-10, INF- $\gamma$, IL-2, and IL-4 were measured with an ELISA kit (R\&D Systems; Shanghai, China) according to the manufacturer's instructions.

Briefly, microtiter plates were coated overnight at room temperature with mouse monoclonal antibodies (the capture antibody); after which, the wells were blocked for $1 \mathrm{~h}$ with PBS containing $1 \%$ FBS and then washed four times with $0.05 \%$ Tween-20 in PBS. Triplicate standards and samples were added to adjacent wells and incubated for $2 \mathrm{~h}$ at room temperature. After incubation, the wells were washed and the detection antibodies were added. After $2 \mathrm{~h}$, the wells were washed again, and incubated with a horse radish peroxidase (HRP)-conjugated antibody in 1\% FBS/PBS. Next, the plates were washed four times and incubated for $30 \mathrm{~min}$ with the substrate $\left(0.0125 \%\right.$ tetramethylbenzidine $/ 0.008 \% \mathrm{H}_{2} \mathrm{O}_{2}$ in citrate buffer, pH 5). Color development was terminated by addition of $2 \mathrm{M} \mathrm{H}_{2} \mathrm{SO}_{4}$. The optical density of each well was measured with an ELISA reader, and the cytokine concentration in each well was calculated using a double standard curve (R\&D System, Shanghai, China).

Proliferation and suppression of T cells

To investigate the proliferative capacity of $\operatorname{Tr} 1$ cells induced by $\mathrm{DC}_{\mathrm{LV}-\mathrm{LL}-10}$ in response to the antigen used for their generation, $\mathrm{T}_{\mathrm{DC}}, \mathrm{T}_{\mathrm{GFP}}$ and $\operatorname{Tr} 1$ cells $\left(2 \times 10^{5}\right.$ cells/well) were stimulated for 2 days with irradiated (40 Gy) BM-derived DCs obtained from BALB/c mice $\left(1 \times 10^{5}\right.$ cells/well $)$. A total of $1 \mu \mathrm{Ci}$ of ${ }^{3} \mathrm{H}$-TdR was added 


\section{Cellular Physiology Cell Physiol Biochem 2017;43:353-366 \begin{tabular}{l|l|l} 
and Biochemistry & $\begin{array}{l}\text { DOI: 10.1159/000480415 } \\
\text { Published } 2017\end{array}$ & $\begin{array}{l}\text { C) } 2017 \text { The Author(s). Published by S. Karger AG, Basel } \\
\text { www.karger.com/cpb }\end{array}$ \\
\hline
\end{tabular}}

Wan et al.: Type 1 T Regulatory Cells Induce Transplant-Tolerance

to each well at the start of the final $16 \mathrm{~h}$ of incubation time. Following incubation, the cells were harvested for measurements of incorporated ${ }^{3} \mathrm{H}$-thymidine with a beta-counter. Percent inhibition was calculated with the following equation: 1-experimental c.p.m./(c.p.m. of responder only + c.p.m. of inhibitor only) [17].

$\mathrm{CD}^{+}$and $\mathrm{CD}^{+} \mathrm{T}$ cells proliferation tests were performed to investigate the Ag-specific immunosuppressive function of $\mathrm{DC}_{\mathrm{LV}-\mathrm{IL}-10}$-induced $\mathrm{Tr} 1$ cells. Naive CD8 ${ }^{+} \mathrm{T}$ cells or naive $\mathrm{CD} 4^{+} \mathrm{T}$ cells as effector cells were isolated from the spleens of C57BL/6 mice using a Mouse Naive CD8 ${ }^{+} \mathrm{T}$ Cell or Naive CD4 ${ }^{+}$ T Cell Isolation Kit (StemCell Technologies; Shanghai, China) according to the manufacturer's instructions. Irradiated (40 Gy) BM-derived DCs obtained from BALB/c mice $\left(0.1 \times 10^{5}\right.$ cells/well) were incubated with naive CD8 ${ }^{+} \mathrm{T}$ cells $\left(0.5 \times 10^{5}\right.$ cells/well) in the presence of irradiated (40 Gy) $\mathrm{T}_{\mathrm{DC}}, \mathrm{T}_{\mathrm{GFP}}$ or $\operatorname{Tr} 1$ cells $\left(2 \times 10^{5}\right.$ cells/well) and 2-fold dilutions thereof in 96-well U-bottom plates for 2 days. In the same way, irradiated (40 Gy) BM-derived DCs obtained from BALB/c mice $\left(0.1 \times 10^{5}\right.$ cells/well) were incubated with naive CD4 ${ }^{+}$ $\mathrm{T}$ cells $\left(0.5 \times 10^{5}\right.$ cells/well) in the presence of irradiated (40 Gy) $\mathrm{T}_{\mathrm{DC}}, \mathrm{T}_{\mathrm{GFP}}$ or $\operatorname{Tr} 1$ cells $\left(2 \times 10^{5}\right.$ cells/well) and 2 -fold dilutions thereof in 96-well U-bottom plates for 2 days. When the ratio of $\mathrm{T}_{\mathrm{DC}}, \mathrm{T}_{\mathrm{GFP}}$ or $\mathrm{Tr} 1$ cells to effector cells reached 4:1, neutralizing anti-IL-10 $(10 \mu \mathrm{g} / \mathrm{mL})$ or anti-IFN- $\gamma$ antibodies $(10 \mu \mathrm{g} / \mathrm{mL}) \mathrm{were}$ added to some of the cultures. A total of $1 \mu \mathrm{Ci}$ of ${ }^{3} \mathrm{H}$-TdR was added to each well at the start of the final $16 \mathrm{~h}$ of incubation time. Cell proliferation was then assessed by measuring ${ }^{3} \mathrm{H}$-thymidine incorporation as previously described.

\section{Mixed lymphocyte reaction assays}

Splenocytes (SCs) from BALB/c and C57BL/6 mice were used as stimulator and effector cells, respectively. Irradiated (40 Gy) SCs from BALB/c mice $\left(4 \times 10^{5}\right.$ cells/well) were cultured with SCs from C57BL/6 mice $\left(4 \times 10^{5}\right.$ cells/well) in the presence of irradiated (40 Gy) $\mathrm{T}_{\mathrm{DC}}, \mathrm{T}_{\mathrm{GFP}}$ or $\operatorname{Tr} 1$ cells $\left(1.6 \times 10^{6}\right.$ cells/well) and 2 -fold dilutions thereof for $2 \mathrm{~d}$ in 96 -well U-bottom plates maintained at $37^{\circ} \mathrm{C}$ in a $5 \% \mathrm{CO}^{2}$ atmosphere. A total of $1 \mu \mathrm{Ci}$ of ${ }^{3} \mathrm{H}$-TdR was added to each well at the start of the final $16 \mathrm{~h}$ of incubation time. Cell proliferation was then assessed by measuring ${ }^{3} \mathrm{H}$-thymidine incorporation as previously described.

\section{Allogeneic bone marrow transplantation (BMT) animal study}

For allogeneic BMTs, bone marrow cells (BMCs) and SCs were harvested from donor mice (C57BL/6). The harvested were then resuspended in RPMI-1640 medium containing 10\% FBS and 1\% penicillin/ streptomycin and adjusted to suitable cell concentrations. Recipient mice (BALB/c) were given a lethal dose of radiation (8 Gy) [18] and then intravenously transplanted with donor BMCs $\left(1 \times 10^{7}\right)$ and SCs $\left(4 \times 10^{7}\right)$ [19]. The recipients were randomly assigned to the following groups based on their number of injected $\operatorname{Tr} 1$ cells; control group: BM + T; BM + T + Tr1 cells $\left(2 \times 10^{6}\right)$; $\mathrm{BM}+\mathrm{T}+\mathrm{Tr} 1$ cells $\left(4 \times 10^{6}\right)$. Survival of the mice after BMT was monitored daily for 50 days. Individual clinical indicators of GVHD, including each animal's weight, posture, activity, fur texture, and skin integrity, received a weekly score ranging from 0 to 2 [20, 21]. On day 14 after BMT, the mice were sacrificed for a histopathology evaluation of GVHD. Samples of skin, liver, intestine, and lung tissue were fixed in $10 \%$ formalin and embedded in paraffin. Sections for histology (5 $\mu \mathrm{m})$ were stained with hematoxylin and eosin and scored for GVHD [22].

\section{Statistical analysis}

All statistical analyses were performed using IBM SPSS Statistics for Windows, Version 19.0. Armonk, NY: IBM Corp. All results are expressed as the mean \pm standard deviation (SD). One-way analysis of variance (ANOVA) was performed to assess the effects of a single factor on multiple groups, and the Tukey test was used for post hoc testing. Survival curves were plotted using Kaplan-Meier estimates. A $P$-value $\leq 0.05$ was considered statistically significant.

\section{Results}

Characteristics of DCs transduced with the lentivirus IL-10 vector

To generate $I L-10$ gene modified tolerogenic DCs, we transduced DCs with LV-GFP or LV-IL-10 overnight at $37^{\circ} \mathrm{C}$ at a multiplicity of infection of 100 to obtain $\mathrm{DC}_{\mathrm{GFP}}$ and $\mathrm{DC}_{\text {LV-IL-10. }}$. Examinations by fluorescence microscopy showed that the transduced DCs expressed GFP (Fig. 1A). Our observations indicated that $49.61 \pm 5.23 \%$ of $\mathrm{DC}_{\mathrm{GFP}}$ and $52.16 \pm 6.24 \%$ of $\mathrm{DC}_{\text {LV-IL-10 }}$ expressed GFP $(P>0.05)$ (Fig. 1B). Moreover, FACS sorting results showed that 76.26 


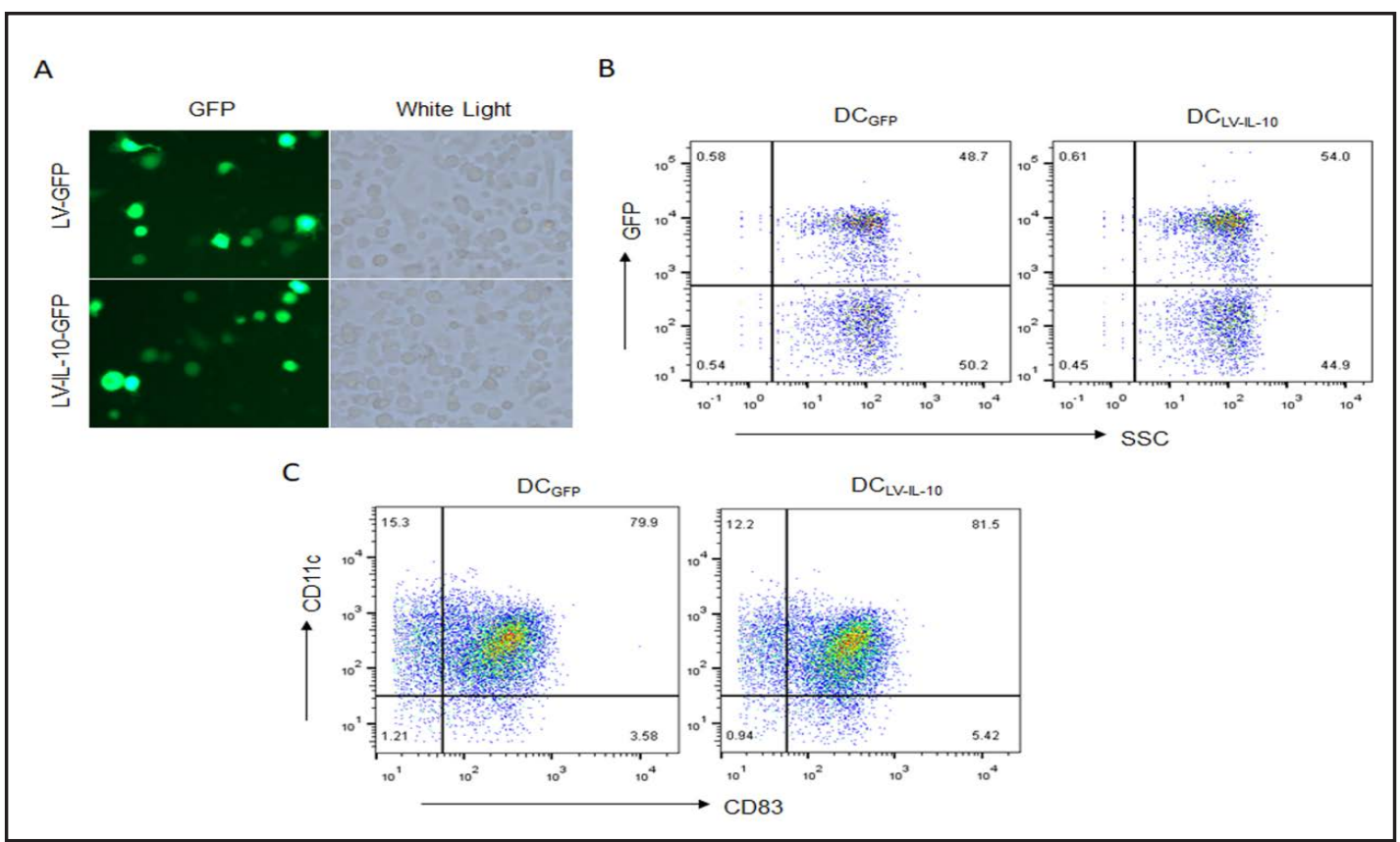

Fig. 1. LV-GFP and LV-IL-10 efficiently transduced DCs without changing their phenotype. (A) Expression of GFP and the morphologic characteristics of $\mathrm{DC}_{\mathrm{GFP}}$ and $\mathrm{DC}_{\mathrm{LV}-\mathrm{IL}-10}$ were observed under a fluorescence microscope (x100 magnification). (B) Transduced DCs were analyzed by FACS. The frequency of GFP positive cells was indicated. (C) Expression of the typical DC markers CD83 and CD11c in GFP positive DCs. Results obtained from at least three independent experiments.

Fig. 2. $\mathrm{DC}_{\mathrm{LV}-\mathrm{IL}-10}$ secreted high levels of IL-10 and IL- 6 but low amounts of TNF- $\alpha$ and IL-12. (A) IL-10 mRNA levels were measured by Real-time PCR; (B) After DCs, $\mathrm{DC}_{\mathrm{GFP}}$ and $\mathrm{DC}_{\mathrm{LV}-\mathrm{IL}-10}$ were activated with LPS and IFN- $\gamma$ for $48 \mathrm{~h}$, the levels of IL-10, IL-6, TNF- $\alpha$, IL-12 were measured by ELISA. Results represent the mean \pm SD of data obtained from at least three independent experiments $\left(* * \mathrm{P}<0.01,{ }^{* * *} \mathrm{P}<0.001\right)$.

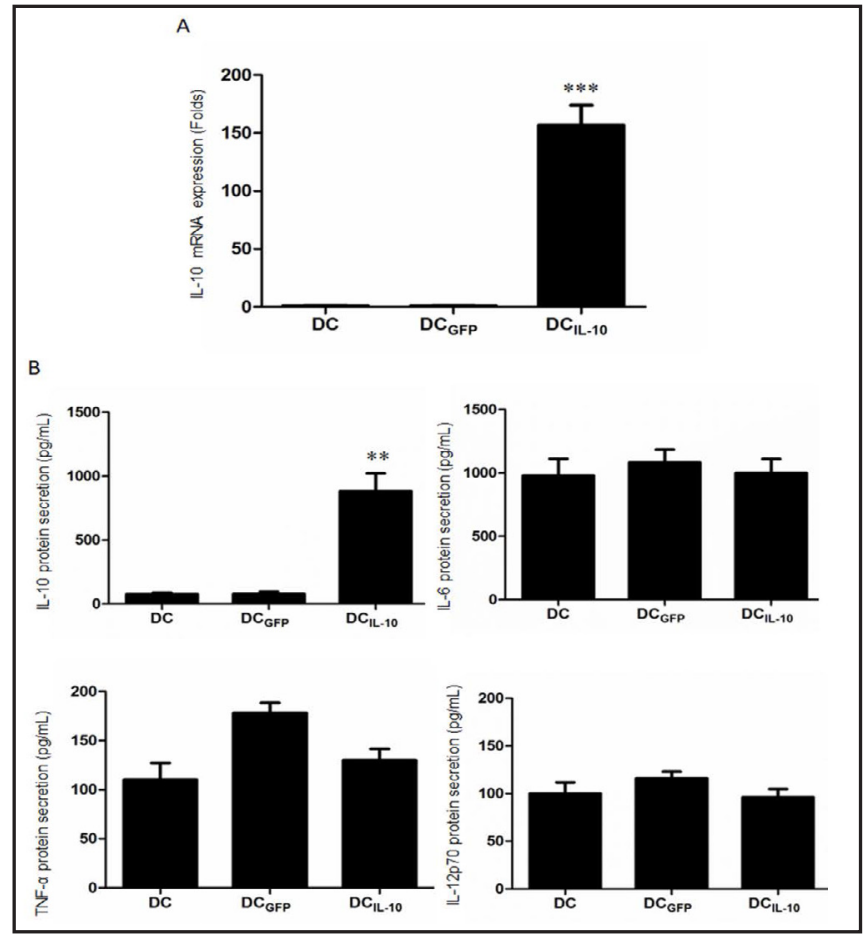

$\pm 9.18 \%$ and $78.39 \pm 8.67 \%$ of GFP positive $\mathrm{DC}_{\mathrm{GFP}}$ and $\mathrm{DC}_{\mathrm{LV}-\mathrm{IL}-10,}$, respectively, expressed CD11c and CD83 $(P>0.05)$ (Fig. 1C), which are markers of mature DCs. 


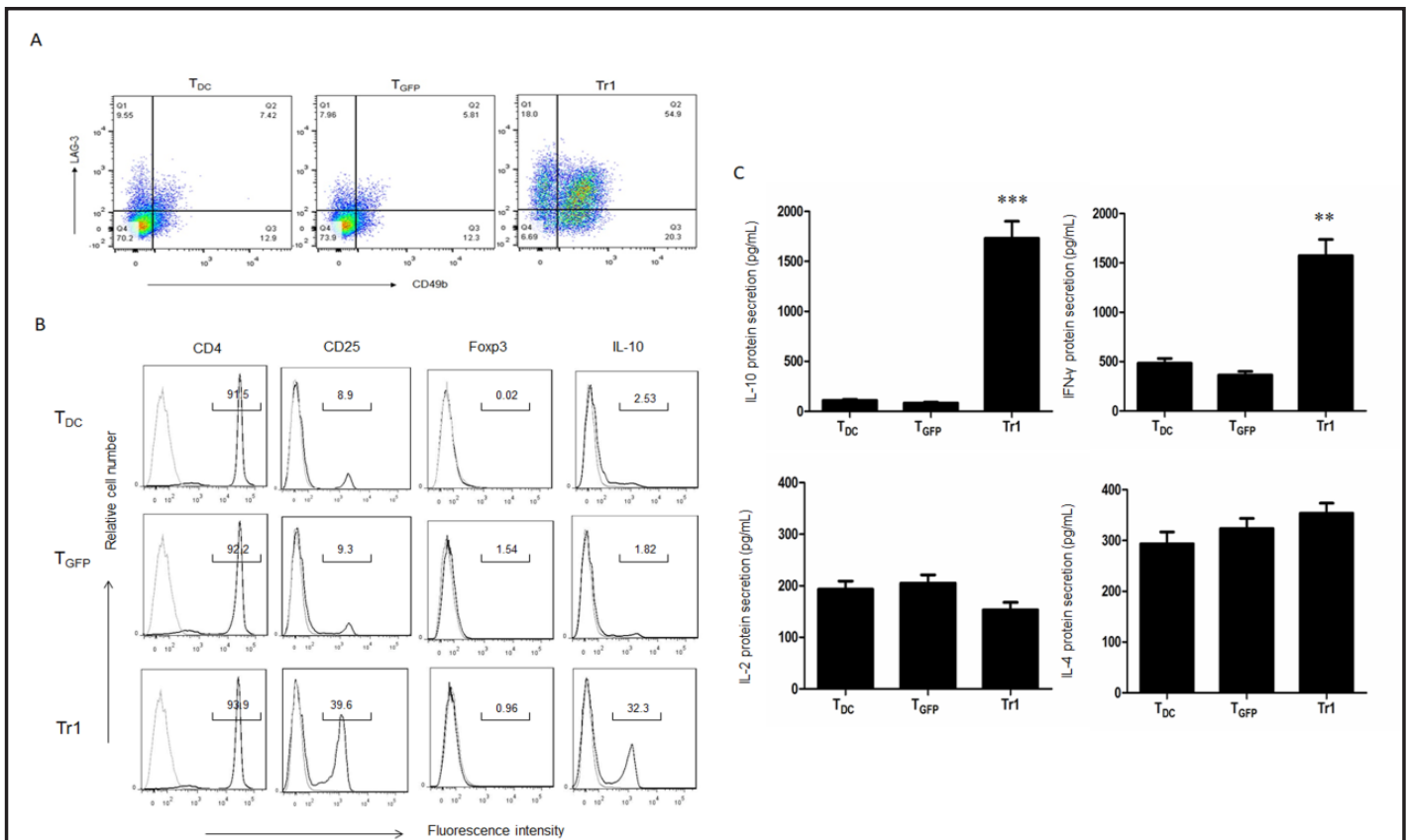

Fig. 3. The characteristics of Tr1 cells which were induced by IL-10 gene-modified DCs. Naive CD $4^{+} \mathrm{T}$ cells were co-cultured with DCs, $\mathrm{DC}_{\mathrm{GFP}}$ and $\mathrm{DC}_{\mathrm{LV}-\mathrm{IL}-10}$ for 3 days in the presence of IL-2. The cells were then purified using a CD4+ $\mathrm{T}$ cell positive enrichment kit, and designated as $\mathrm{T}_{\mathrm{DC}}, \mathrm{T}_{\mathrm{GFP}}$ and $\mathrm{Tr} 1$ cells, respectively. (A) The expression of LAG3 and CD49b, which are the typical markers of Tr1 cells were analyzed by FACS in $\mathrm{DC}_{\mathrm{LV}-\mathrm{IL}-10}$-induced Tr1 cells. (B) CD4, CD25, IL-10 and Foxp3 expression in $\mathrm{DC}_{\mathrm{LV}-\mathrm{LL}-10}$-induced $\operatorname{Tr} 1$ cells were evaluated by FACS. (C) After stimulated with irradiated (40 Gy) BM-derived DCs from BALB/c mice for $48 \mathrm{~h}$, the cytokine profile of $\mathrm{DC}_{\mathrm{LV}-\mathrm{LL}-10}$-induced Tr1 cells were measured by ELISA. Results represent the mean $\pm \mathrm{SD}$ of data obtained from at least three independent experiments $\left(* * \mathrm{P}<0.01,{ }^{* * *} \mathrm{P}<0.001\right)$.

IL-10 mRNA expression on $\mathrm{DC}_{\mathrm{LV}-\mathrm{LL}-10}$ was significantly higher than that on $\mathrm{DCs}$ and $\mathrm{DC}_{\mathrm{GFP}}$ $(\mathrm{P}<0.001)$ (Fig. 2A). We also used ELISA to detect the levels of cytokines secreted by DCs, $\mathrm{DC}_{\mathrm{GFP}}$ and $\mathrm{DC}_{\mathrm{LV}-\mathrm{LL}-10}$ that had been activated with LPS and IFN- $\gamma$. As shown in Fig. 2B, the levels of IL-10 secreted by $\mathrm{DC}_{\mathrm{IV}-\mathrm{LL}-10}(923.65 \pm 85.37 \mathrm{pg} / \mathrm{mL})$ were significantly higher than the levels secreted by DCs $(84.76 \pm 7.19 \mathrm{pg} / \mathrm{mL})$ and $\mathrm{DC}_{\mathrm{GFP}}(95.33 \pm 9.17 \mathrm{pg} / \mathrm{mL})(P<0.01)$. However, there were no significant differences between the levels IL-6, TNF- $\alpha$ and IL-12p70 secreted by $\mathrm{DC}_{\mathrm{LV}-\mathrm{IL}-10}$ when compared with those levels secreted by $\mathrm{DCs}$ and $\mathrm{DC}_{\mathrm{GFP}}(\mathrm{P}>0.05)$.

Taken together, our data suggest that DCs can be successfully transduced with LV-IL-10 and maintain the morphology and phenotype of mature DCs; and at the same time, express high levels of IL-10. They therefore possess the properties needed to induce a population of Tr1 cells.

\section{Induction of Tr1 cells by IL-10 gene modified DCs}

To determine whether or not $\mathrm{DC}_{\mathrm{LV}-\mathrm{LL}-10}$ could induce $\mathrm{Tr} 1$ cells, naive $\mathrm{CD} 4^{+} \mathrm{T}$ cells were co-cultured with $\mathrm{DCs}, \mathrm{DC}_{\mathrm{GFP}}$ or $\mathrm{DC}_{\mathrm{LV}-\mathrm{IL}-10}$ for 3 days in the presence of rmIL-2. The cells were then purified using a $\mathrm{CD} 4^{+} \mathrm{T}$ cell positive enrichment kit, and designated as $\mathrm{T}_{\mathrm{DC}}, \mathrm{T}_{\mathrm{GFP}}$ or $\operatorname{Tr} 1$ cells respectively. We next analyzed whether $\mathrm{DC}_{\mathrm{LV}-\mathrm{IL}-10}$-induced $\mathrm{Tr} 1$ cells express $\mathrm{Tr} 1$ cellassociated surface markers [10] and/or transcription factors [12]. As shown in Figs. 3A and 3B, $51.27 \pm 3.86 \%$ of $\mathrm{DC}_{\mathrm{LV}-\mathrm{LL}-10}$-induced Tr1 cells co-expressed CD49b and LAG-3. Moreover, they also expressed CD4, CD25, and IL-10, but not Foxp3. Next, the cytokines secreted by $\mathrm{DC}_{\mathrm{LV}-\mathrm{LL}-10}$-induced $\mathrm{T}$ cells were analyzed by ELISA, and our results showed that Tr1 cells secreted significantly higher levels of IL-10 $(1,729.36 \pm 185.79 \mathrm{pg} / \mathrm{mL})$ than $\mathrm{T}_{\mathrm{DC}}(115.82$ $\pm 13.29 \mathrm{pg} / \mathrm{mL})$ and $\mathrm{T}_{\text {GFP }}$ did $(90.34 \pm 11.83 \mathrm{pg} / \mathrm{mL})(P<0.001)$. Similarly, the levels of INF- $\gamma$ secreted by $\operatorname{Tr} 1$ cells $(1,524.48 \pm 168.65 \mathrm{pg} / \mathrm{mL})$ were significantly higher than those KARGER 
Fig. 4. Tr1 cells were anergic and inhibited cell proliferation in vitro. (A) $\mathrm{T}_{\mathrm{DC}}, \mathrm{T}_{\mathrm{GFP}}$ and $\mathrm{Tr} 1$ cells were stimulated with DCs from BALB/c mice. Naive $\mathrm{CD}^{+} \mathrm{T}$ cells (B) and naive $\mathrm{CD}^{+} \mathrm{T}$ cells (C) from $\mathrm{C} 57 \mathrm{BL} / 6$ mice were stimulated with DCs from BALB/c mice alone or in the presence of $\mathrm{T}_{\mathrm{DC}}, \mathrm{T}_{\mathrm{GFP}}$ and $\mathrm{Tr} 1$ cells at different ratios. When the ratio of $\mathrm{T}_{\mathrm{DC}}, \mathrm{T}_{\mathrm{GFP}}$ or $\operatorname{Tr} 1$ cells to effector cells reached 4:1, neutralizing anti-IL-10 or anti-IFN- $\gamma$ antibodies were added to the cultures. (D) SCs from C57BL/6 mice were stimulated with irradiated SCs from BALB/c mice alone or in the presence of $\mathrm{T}_{\mathrm{DC}}, \mathrm{T}_{\mathrm{GFP}}$ and $\mathrm{Tr} 1$ cells at different ratios. After two days of culture, $\left[{ }^{3} \mathrm{H}\right]$-thymidine was incubated with the cells for 16 hours. Results represent the mean \pm SD of data obtained from least three independent experiments $\left({ }^{*} \mathrm{P}<0.01,{ }^{* *} \mathrm{P}<0.001\right)$.

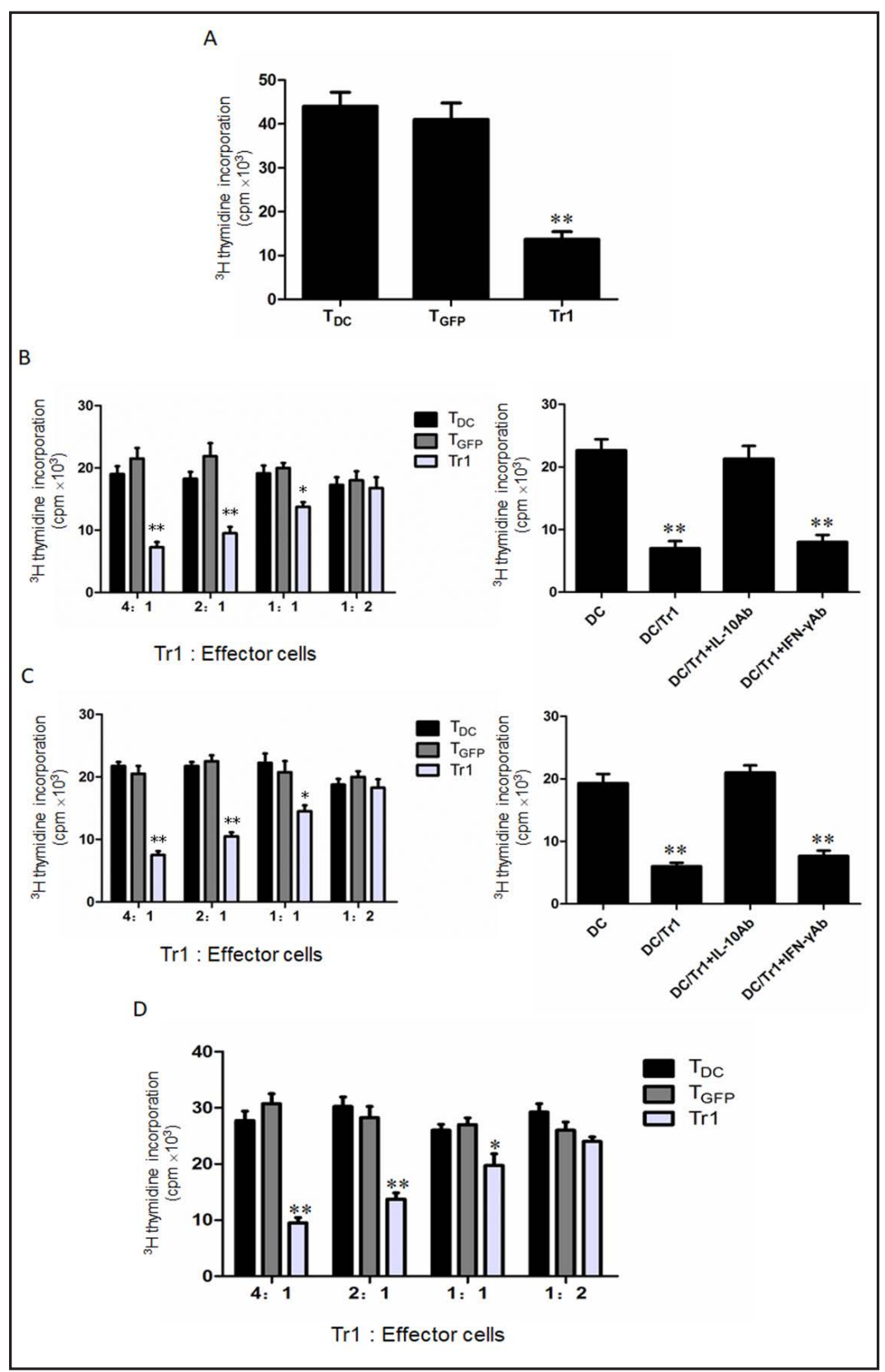

secreted by $\mathrm{T}_{\mathrm{DC}}(496 \pm 72.56 \mathrm{pg} / \mathrm{mL})$ and $\mathrm{T}_{\mathrm{GFP}}(368 \pm 65.79 \mathrm{pg} / \mathrm{mL})(P<0.01)$. However, the IL-2 and IL-4 levels secreted by Tr1 cells were not significantly different from those secreted by $\mathrm{T}_{\mathrm{DC}}$ and $\mathrm{T}_{\mathrm{GFP}}(P>0.05)$ (Fig. 3C).

These data showed that $\mathrm{DC}_{\mathrm{LV}-\mathrm{L}-10}$ co-cultured with naive $\mathrm{CD} 4^{+} \mathrm{T}$ cells could induce $\operatorname{Tr} 1$ cells that secrete high levels of IL-10 and IFN- $\gamma$, which are the main cytokines required for Tr1 cells to exert an immunosuppressive effect.

Tr1 cells were capable of inhibiting T-cell proliferation in vitro

To determine whether our induced Tr1 cells were anergic, $\mathrm{T}_{\mathrm{DC}}, \mathrm{T}_{\mathrm{GFP}}$ or $\operatorname{Tr} 1$ cells were re-stimulated with DCs obtained from BALB/c mice. Our results showed that the $\operatorname{Tr} 1$ cells exhibited a significantly lower proliferative response when compared with $\mathrm{T}_{\mathrm{DC}}$ and $\mathrm{T}_{\mathrm{GFP}}$ $(P<0.01)$ (Fig. 4A). This indicated that the Tr1 cells were Ag-specific anergic toward the antigen used for their generation. 
Fig. 5. Effect of a Tr1 cell infusion on graft versus host disease (GVHD) in BALB/c mice. (A) Clinical GVHD scores of the transplanted mice. Results represent the mean \pm SD of data gathered from one of three independent experiments $(n=12$ mice per group). (B) Histopathology results are shown for samples of skin, small intestine, liver, and lung tissue. The sections were stained with H\&E on day 14 after BMT. Results obtained from a least three independent experiments ( $\mathrm{n}=5$ mice per group); (original magnification $\times 100$ ). (C) Histopathology scores for samples of skin, small intestine, liver, and lung tissue on day 14 after BMT. Results represent the mean \pm SD of data obtained from one of three independent experiments $(\mathrm{n}=5$ per group $) \quad(* \mathrm{P}<0.05$, $* * \mathrm{P}<0.01)$.

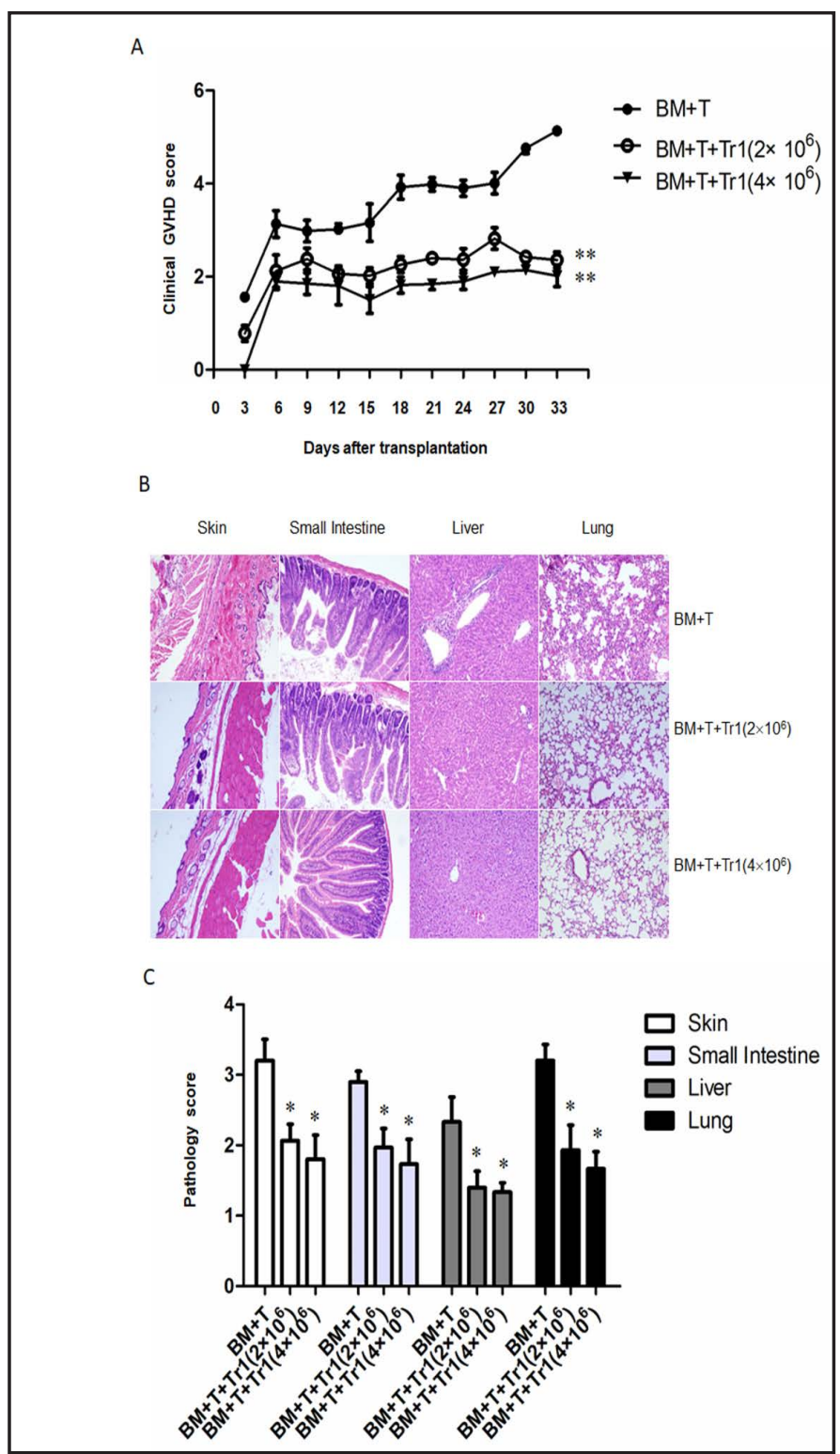

The suppressive effect of $\operatorname{Tr} 1$ cells was examined in a $\mathrm{CD}^{+} / \mathrm{CD} 4^{+} \mathrm{T}$ cell proliferation assay. Irradiated $\left(40 \mathrm{~Gy}\right.$ ) $\mathrm{T}_{\mathrm{DC}}, \mathrm{T}_{\mathrm{GFP}}$ or $\mathrm{Tr} 1$ cells were added to cultures containing naive $\mathrm{CD}^{+}$ $\mathrm{T}$ cells or naive $\mathrm{CD} 4^{+} \mathrm{T}$ cells obtained from C57BL/6 mice and also irradiated (40 Gy) DCs obtained from BALB/c mice at different ratios of $\mathrm{T}_{\mathrm{DC}}, \mathrm{T}_{\mathrm{GFP}}$ or $\operatorname{Tr} 1$ : effector cells $(4: 1,2: 1$, 1:1, and 1:2). As shown in Figs. 4B and 4C, the Tr1 cells markedly inhibited CD8 ${ }^{+}$and CD4 ${ }^{+}$ $\mathrm{T}$ cell proliferation when the Tr1/effector cell ratio was 4:1 $(P<0.01), 2: 1(P<0.01)$ or 1:1 $(P<0.05)$. The strongest suppressive effect was obtained when the ratio was $4: 1$, and no suppressive effect was observed when the Tr1 to effector cell ratio was $1: 2$, indicating that $\mathrm{Tr} 1$ cells inhibited $\mathrm{CD} 8^{+}$and $\mathrm{CD} 4^{+} \mathrm{T}$ cell proliferation in a dose-dependent manner. To determine the role played by IL-10 in the suppressive effect of Tr1 cells, neutralizing antiIL-10 and IFN- $\gamma$ antibodies were added to some of the cultures. When the ratio of $\mathrm{T}_{\mathrm{DC}} \mathrm{T}_{\mathrm{GFP}}$ or Tr1 cells to effector cells reached $4: 1$, the inhibitory effect of $\operatorname{Tr} 1$ cells was decreased $>90 \%$ by anti-IL-10 antibodies $(P<0.01)$, but not by anti-IFN- $\gamma$ antibodies $(P>0.05)$, indicating that IL-10 plays an important role in the suppressive activity of regulatory T cells.

MLR assays were performed to further confirm the immunosuppressive effect of $\mathrm{DC}_{\mathrm{LV}-\mathrm{LL}-10}$-induced Tr1 cells. Irradiated (40 Gy) $\mathrm{T}_{\mathrm{DC}}, \mathrm{T}_{\mathrm{GFP}}$ or Tr1 cells accompanied by effector 
Fig. 6. Effect of a $\operatorname{Tr} 1$ cell infusion on the survival of transplanted mice. $\mathrm{BALB} / \mathrm{c}$ mice were infused with BM $+\mathrm{T}, \mathrm{BM}+\mathrm{T}+\mathrm{Tr} 1$ cells $\left(2 \times 10^{6}\right)$ or $\mathrm{BM}+\mathrm{T}+\mathrm{Tr} 1$ cells $\left(4 \times 10^{6}\right)$, and their survival times were recorded over a period of 50 days. Results obtained from one of three independent experiments $(\mathrm{n}=12$ per group); $\left({ }^{*} \mathrm{P}<0.05,{ }^{* *} \mathrm{P}<0.01\right)$.

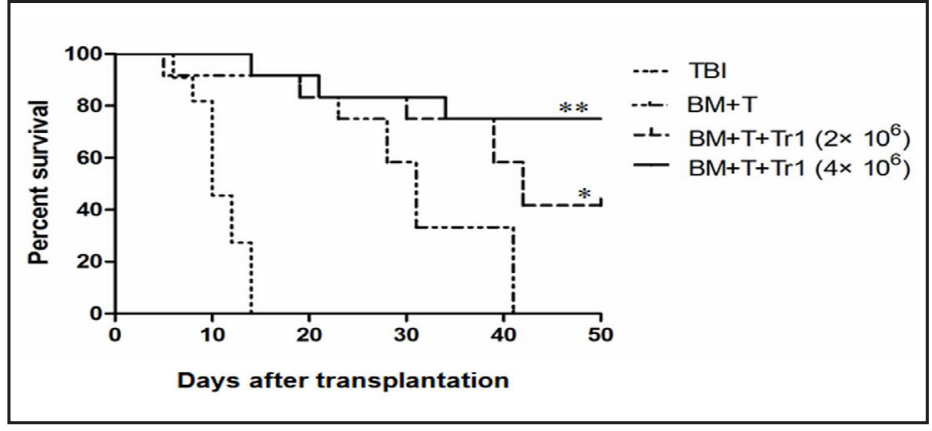

cells at different ratios of $\mathrm{T}_{\mathrm{DC}}, \mathrm{T}_{\mathrm{GFP}}$ or $\operatorname{Tr} 1$ to effector cells $(4: 1,2: 1,1: 1$, and 1:2) were added to cultures containing SCs obtained from BALB/c and C57BL/6 mice. As shown in Fig. 4D, Tr1 cells inhibited the MLR in a dose-dependent manner. The strongest suppressive effect was obtained when the ratio of $\operatorname{Tr} 1$ to effector cells was $4: 1(P<0.01)$, and no suppressive effect was found when the Tr1 to effector cell ratio was $1: 2(P>0.05)$.

Taken together, our data suggest that the $\mathrm{DC}_{\mathrm{LV}-\mathrm{LL}-10}$-induced $\mathrm{Tr} 1$ cells were Ag-specific anergic, and capable of inhibiting $\mathrm{CD}^{+}$and $\mathrm{CD}^{+} \mathrm{T}$ cell proliferation and the MLR in vitro.

$D C_{L V-L L-10}$-induced Tr1 cells induced transplant tolerance after an allogeneic bone marrow transplantation

We next investigated whether $\mathrm{DC}_{\mathrm{LV}-\mathrm{LL}-10}$-induced $\operatorname{Tr} 1$ cells could inhibit alloreactivity and induce transplant-tolerance in vivo. Recipient BALB/c mice were given a lethal dose of radiation, and then infused with BMCs and SCs obtained from donor C57BL/6 mice with or without accompanying $\mathrm{DC}_{\mathrm{LV}-\mathrm{IL}-10}$-induced $\mathrm{Tr} 1$ cells. The transplanted mice were monitored for signs and symptoms of GVHD. As shown in Fig. 5A, the GVHD scores of mice which received $\mathrm{BM}+\mathrm{T}+\mathrm{Tr} 1$ cells were significantly lower from day 6 onwards when compared with the GVHD scores of the control mice $(P<0.01)$.

Histopathological analyses of tissue sections revealed that the control mice displayed more obvious signs of GVHD in specimens of their skin, intestine, liver, and lung tissue on day 14 after the BMT, when compared with mice in the Tr1-treated groups (Fig. 5B). We also used pathology scores to confirm the effect of a Tr1 cell infusion on GVHD. As shown in Fig. 5C, the histopathological GVHD scores of mice which received BM $+\mathrm{T}+\mathrm{Tr} 1$ cells were significantly lower than those of the control mice with regards to skin, small intestine, liver, and lung damage (all $P$-values $<0.05$ ). Furthermore, it appeared that the GVHD scores of mice which received a high dose of Tr1 cells $\left(4 \times 10^{6}\right)$ were lower than those of mice which received a low dose $\left(2 \times 10^{6}\right)$ of $\operatorname{Tr} 1$ cells. However, this difference was not statistically significant $(P>0.05)$.

Our data also suggest that an infusion of $\operatorname{Tr} 1$ cells prolonged the mean survival time of the transplanted mice. As shown in Fig. 6, the mean survival time of mice infused with BM + $\mathrm{T}$ was $28.7 \pm 1.02 \mathrm{~d}$, which was significantly less than the mean survival time of mice which received $\mathrm{BM}+\mathrm{T}+\operatorname{Tr} 1$ cells $\left(2 \times 10^{6}\right)(39.5 \pm 3.02 \mathrm{~d})(P<0.05)$, as well as the mice which received $\mathrm{BM}+\mathrm{T}+\mathrm{Tr} 1$ cells $\left(4 \times 10^{6}\right)$ (mean survival time point not reached) $(P<0.01)$. At 50 days post-transplantation, $75 \%$ of the BALB/c mice that received BM $+\mathrm{T}+\mathrm{Tr} 1$ cells $\left(4 \times 10^{6}\right)$ remained alive, whereas only $40 \%$ of the mice that received $\mathrm{BM}+\mathrm{T}+\mathrm{Tr} 1$ cells $(2$ $\times 10^{6}$ ) were still alive $(P<0.05)$, indicating that infusing greater numbers of Tr1 cells could further increase the survival time of BMC-transplanted mice.

\section{Discussion}

Tregs play a crucial role in the induction of peripheral tolerance to self and foreign antigens, and can potentially be developed as a therapeutic tool to promote or restore immune tolerance in patients who have received a transplant or have inflammatory or 
autoimmune diseases. The major obstacles to developing Tregs as therapeutic agents have been an inability to efficiently expand pure cultures of polyclonal Tregs and generate Agspecific Tregs. Despite recent advances in the methods used to generate antigen Ag-specific Tr1 cells in vitro, the resulting populations still contain contaminants that may limit the in vivo efficacy of the cultured Tr1 cells $[17,23]$.

Adaptive $\operatorname{Tr} 1$ cells are generated peripherally when dendritic cells present antigens to naive T cells; after which, the resultant adaptive Tr1 cells can assume a variety of phenotypes depending upon the conditions under which they are induced. It was previously shown that IL-10 and TGF- $\beta$-secreting Tr1 cells are generated upon Ag-presentation by immature DCs and also DCs that express IL-10 or TGF- $\beta[24,25]$.

In this study, $78.39 \pm 8.67 \%$ of $\mathrm{DC}_{\mathrm{LV}-\mathrm{LL}-10}$ sorted by FACS displayed morphologic and phenotypic characteristics typical of mature DCs. The IL-10 levels secreted by $\mathrm{DC}_{\mathrm{LV}-\mathrm{LL}-10}$ were higher than those secreted by $\mathrm{DCs}$ and $\mathrm{DC}_{\mathrm{GFP}}$, and were satisfactory to induce a population of $\operatorname{Tr} 1$ cells [17]. Subsequently, we incubated naive $C D 4^{+} \mathrm{T}$ cells with irradiated $\mathrm{DC} \mathrm{LV}_{\mathrm{LV}-\mathrm{L}-10}$ for 3 days, and found that $51.27 \pm 3.86 \%$ of the purified T cells co-expressed CD49b and LAG-3, which are Tr1-related phenotypic markers [10]. Moreover, the Tr1 cells also expressed CD4, CD25 and IL-10, but not Foxp3 [12]. After re-stimulation in vitro, the Tr1 cells secreted high levels of IL-10 and IFN- $\gamma$, but only low levels IL-4 and IL-2. Taken together, our data suggest that LV-IL-10-transduced DCs are capable of stimulating the differentiation of naive CD4+ T cells into Tr1 cells that secrete the characteristic cytokines, IL-10 and IFN- $\gamma[10,26,27]$. Notably, when $\operatorname{Tr} 1$ cells were re-stimulated with the antigen used for their generation, the cells exhibited a significant hyporesponsiveness to re-stimulation. That result indicated that the Tr1 cells were Ag-specific anergic toward the antigen used for their priming [13].

Tregs can suppress the proliferation of $\mathrm{CD}^{+}$and $\mathrm{CD} 4^{+} \mathrm{T}$ cells in part, by inhibiting IL-2 production, or reducing the effector function of T cells $[5,28,29]$. They can also transfer their suppressive properties to other $\mathrm{CD} 4^{+} \mathrm{T}$ cells, resulting in new $\mathrm{CD} 4$ suppressive $\mathrm{T}$ cells or T cell anergy [30-32]. Additionally, Tregs can downregulate MHC II, CD80, and CD86 expression on DCs and induce indoleamine 2, 3-dioxygenase (IDO) expression [33, 34].

We performed Tr1-mediated T cell proliferation and MLR inhibition assays to determine whether the $\mathrm{Tr} 1$ cells suppressed $\mathrm{CD}^{+}$or $\mathrm{CD} 4^{+} \mathrm{T}$ cells. Our results showed that $\mathrm{DC}_{\mathrm{LV}-\mathrm{LL}-10}$ induced $\mathrm{Tr} 1$ cells could significantly suppress both $\mathrm{CD}^{+} \mathrm{T}$ and $\mathrm{CD} 4^{+} \mathrm{T}$ cell proliferation and the MLR in vitro in dose-dependent manners. Furthermore, addition of anti-IL-10, but not anti-IFN- $\gamma$ antibodies to the $\mathrm{CD}^{+} \mathrm{T}$ and $\mathrm{CD} 4^{+} \mathrm{T}$ cell cultures assays caused $\mathrm{Tr} 1$ cell proliferation to be inhibited by $>90 \%$, suggesting that IL-10 is crucial for the activity of these regulatory T cells.

IL-10 is an immune regulatory cytokine that is indispensable for controlling inflammation, downregulating immune responses, and inducing tolerance [35]. Importantly, IL-10 induces the differentiation of Tr1 cells and long-lasting Ag-specific T-cell anergy in both humans [36] and mice [37]. Although IL-10 is essential for inducing $\operatorname{Tr} 1$ cells, when used in vitro, its function requires the presence of APCs $[15,38]$. Some studies have also shown that $\mathrm{T}$ cell priming drives the differentiation of Tr1 cells in vitro by immature DC or DCs rendered tolerogenic by biologic or pharmacologic agents [38].

The suppressive function of natural regulatory T cells is Ag-nonspecific [39]. However, we previously demonstrated that $\mathrm{CD} 4^{+} \mathrm{CD} 25^{+}$Tregs can acquire Ag-specificity via the uptake of Ag-specific DC-released exosomes (EXO) [12]. In a previous study, CD4+CD25+ Tregs with acquired pMHC I complexes (Ag-specificity) displayed a greater ability to inhibit Ag-specific immunity than Tregs without pMHC I [12]. Yamazaki et al [40]. demonstrated that under in vitro conditions, either Ag-specific DCs or non-specific DCs administered in combination with IL-2 could stimulate the proliferation of fully functional CD $4^{+} \mathrm{CD} 25^{+}$Tregs. This suggests that cognate Ag-unrelated $\mathrm{CD} 4^{+} \mathrm{CD} 25^{+}$Tregs in peripheral blood can also be expanded by incubation with DCs presenting cognate Ag, and that the pMHC I and pMHC II complexes acquired from those DCs by the CD $4^{+}$Tregs may produce some degree of Ag-specificity.

Sanchez-Fueyo et al [25]. demonstrated that Ag-specific Tregs derived from T cell receptor (TCR)-transgenic mice inhibit immune responses more effectively than do polyclonal Tregs 


\section{Cellular Physiology Cell Physiol Biochem 2017;43:353-366 \begin{tabular}{ll|l} 
DOI: 10.1159/000480415 & C 2017 The Author(s). Published by S. Karger AG, Basel \\
www.karger.com/cpb
\end{tabular}

obtained from non-transgenic mice. Furthermore, Ag-specific Tregs have been shown to be more effective than polyclonal Tregs in preventing graft rejection in humanized pre-clinical models $[41,42]$. Therefore, we speculated that during induction of $\mathrm{Tr} 1$ cells, $\mathrm{DC}_{\mathrm{LV}-\mathrm{IL}-10}$ derived from recipient mice might present the pMHC I and pMHC II complexes of recipient mice to $\operatorname{Tr} 1$ cells derived from donor mice. These Tr1 cells might then suppress the response of donor $\mathrm{T}$ cells towards their specific Ag, and thereby induce immune tolerance of donor $\mathrm{T}$ cells after an allogeneic BMT. In our study, the recipient mice were infused with BMCs and SCs obtained from donor mice to induce GVHD after a lethal dose of radiation. Infusing recipient mice with $\mathrm{DC}_{\mathrm{LV}-\mathrm{LL}-10}$-induced donor mouse $\operatorname{Tr} 1$ cells remarkably reduced the severity of GVHD. This was shown by the significantly lower histopathological and clinical GVHD scores among the mice treated with Tr1 cells rather than control cells. Furthermore, the transplanted mice in the Tr1-infused groups survived significantly longer than mice in the control group. Additionally, mice infused with $4 \times 10^{6} \operatorname{Tr} 1$ cells survived longer than mice infused with $2 \times 10^{6} \operatorname{Tr} 1$ cells, indicating that the suppressive effect of Tr1 cells was dose-dependent manner. In conclusion, ex vivo induction and expansion of Tr1 cells achieved by co-culturing IL-10 gene-modified DCs with naive CD $4^{+} \mathrm{T}$ cells is a promising approach for inducing $\operatorname{Tr} 1$ cells, and may be used to facilitate the development of cellular therapies for graft versus-host disease and other autoimmune diseases.

\section{Acknowledgements}

This work was supported by the Nature Science Foundation of China (Grant (No. 81170527).

\section{Disclosure Statement}

The authors have no competing interests to disclose.

\section{References}

1 Sakaguchi S, Yamaguchi T, Nomura T, Ono M: Regulatory T cells and immune tolerance. Cell 2008;133:775787.

2 Sela U, Olds P, Park A, Schlesinger SJ, Steinman RM: Dendritic cells induce antigen-specific regulatory T cells that prevent graft versus host disease and persist in mice. J Exp Med 2011;208:2489-2496.

- Ma H, Lu C, Ziegler J, Liu A, Sepulveda A, Okada H, Lentzsch S, Mapara MY: Absence of Stat1 in donor CD4(+) T cells promotes the expansion of Tregs and reduces graft-versus-host disease in mice. J Clin Invest 2011;121:2554-2569.

4 Ebrahimi A, Hosseini SA, Rahim F: Immunosuppressive therapy in allograft transplantation: from novel insights and strategies to tolerance and challenges. Cent Eur J Immunol 2014;39:400-409.

5 Levings MK, Sangregorio R, Roncarolo MG: Human cd25(+)cd4(+) t regulatory cells suppress naive and memory $\mathrm{T}$ cell proliferation and can be expanded in vitro without loss of function. J Exp Med 2001;193:1295-1302.

6 Hall BM, Robinson CM, Plain KM, Verma ND, Carter N, Boyd RA, Tran GT, Hodgkinson SJ: Studies on naive CD4+CD25+T cells inhibition of naive CD4+CD25- T cells in mixed lymphocyte cultures. Transpl Immunol 2008;18:291-301.

7 Hoffmann P, Ermann J, Edinger M, Fathman CG, Strober S: Donor-type CD4(+)CD25(+) regulatory T cells suppress lethal acute graft-versus-host disease after allogeneic bone marrow transplantation. J Exp Med 2002;196:389-399.

8 Tang Q, Lee K: Regulatory T-cell therapy for transplantation: how many cells do we need? Curr Opin Organ Transplant 2012;17:349-354. 


\section{Cellular Physiology Cell Physiol Biochem 2017;43:353-366

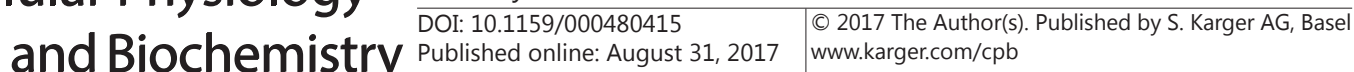

Wan et al.: Type $1 \mathrm{~T}$ Regulatory Cells Induce Transplant-Tolerance

9 Allan SE, Crome SQ, Crellin NK, Passerini L, Steiner TS, Bacchetta R, Roncarolo MG, Levings MK: Activationinduced FOXP3 in human T effector cells does not suppress proliferation or cytokine production. Int Immunol 2007;19:345-354.

10 Gagliani N, Magnani CF, Huber S, Gianolini ME, Pala M, Licona-Limon P, Guo B, Herbert DR, Bulfone A, Trentini F, Di Serio C, Bacchetta R, Andreani M, Brockmann L, Gregori S, Flavell RA, Roncarolo MG: Coexpression of CD49b and LAG-3 identifies human and mouse T regulatory type 1 cells. Nat Med 2013;19:739-746.

11 Bacchetta R, Bigler M, Touraine JL, Parkman R, Tovo PA, Abrams J, de Waal Malefyt R, de Vries JE, Roncarolo MG: High levels of interleukin 10 production in vivo are associated with tolerance in SCID patients transplanted with HLA mismatched hematopoietic stem cells. J Exp Med 1994;179:493-502.

12 Hao S, Yuan J, Xu S, Munegowda MA, Deng Y, Gordon J, Xing Z, Xiang J: Antigen specificity acquisition of adoptive CD4+ regulatory T cells via acquired peptide-MHC class I complexes. J Immunol 2008;181:24282437.

13 Roncarolo MG, Gregori S, Bacchetta R, Battaglia M: Tr1 cells and the counter-regulation of immunity: natural mechanisms and therapeutic applications. Curr Top Microbiol Immunol 2014;380:39-68.

14 Magnani CF, Alberigo G, Bacchetta R, Serafini G, Andreani M, Roncarolo MG, Gregori S: Killing of myeloid APCs via HLA class I, CD2 and CD226 defines a novel mechanism of suppression by human Tr1 cells. Eur J Immunol 2011;41:1652-1662.

15 Levings MK, Sangregorio R, Galbiati F, Squadrone S, de Waal Malefyt R, Roncarolo MG: IFN-alpha and IL-10 induce the differentiation of human type $1 \mathrm{~T}$ regulatory cells. J Immunol 2001;166:5530-5539.

16 Pot C, Jin H, Awasthi A, Liu SM, Lai CY, Madan R, Sharpe AH, Karp CL, Miaw SC, Ho IC, Kuchroo VK: Cutting edge: IL-27 induces the transcription factor c-Maf, cytokine IL-21, and the costimulatory receptor ICOS that coordinately act together to promote differentiation of IL-10-producing $\operatorname{Tr} 1$ cells. J Immunol 2009;183:797-801.

17 Gregori S, Tomasoni D, Pacciani V, Scirpoli M, Battaglia M, Magnani CF, Hauben E, Roncarolo MG: Differentiation of type $1 \mathrm{~T}$ regulatory cells (Tr1) by tolerogenic DC-10 requires the IL-10-dependent ILT4/ HLA-G pathway. Blood 2010;116:935-944.

18 Andolfi G, Fousteri G, Rossetti M, Magnani CF, Jofra T, Locafaro G, Bondanza A, Gregori S, Roncarolo MG: Enforced IL-10 expression confers type 1 regulatory T cell (Tr1) phenotype and function to human CD4(+) T cells. Mol Ther 2012;20:1778-1790.

19 Huang XJ, Zhao J, Zhao XY, Chang YJ: Treating donor mice with rhIL-11 and rhG-CSF promotes transplanttolerance and preserves the effects of GVL after allogeneic bone marrow transplantation. Leuk Res 2009;33:123-128.

20 Cooke KR, Kobzik L, Martin TR, Brewer J, Delmonte J, Jr., Crawford JM, Ferrara JL: An experimental model of idiopathic pneumonia syndrome after bone marrow transplantation: I. The roles of minor $\mathrm{H}$ antigens and endotoxin. Blood 1996;88:3230-3239.

21 Qiao SK, Ren HY, Shi YJ, Liu W: Allogeneic Compact Bone-Derived Mesenchymal Stem Cell Transplantation Attenuates the Severity of Idiopathic Pneumonia Syndrome in a Murine Bone Marrow Transplantation Model. Cell Physiol Biochem 2016;40:1656-1669.

-22 Nervi B, Rettig MP, Ritchey JK, Wang HL, Bauer G, Walker J, Bonyhadi ML, Berenson RJ, Prior JL, PiwnicaWorms D, Nolta JA, DiPersio JF: Factors affecting human T cell engraftment, trafficking, and associated xenogeneic graft-vs-host disease in NOD/SCID beta2mnull mice. Exp Hematol 2007;35:1823-1838.

-23 Bacchetta R, Gregori S, Serafini G, Sartirana C, Schulz U, Zino E, Tomiuk S, Jansen U, Ponzoni M, Paties CT, Fleischhauer K, Roncarolo MG: Molecular and functional characterization of allogantigen-specific anergic $\mathrm{T}$ cells suitable for cell therapy. Haematologica 2010;95:2134-2143.

24 Huang X, Zhu J, Yang Y: Protection against autoimmunity in nonlymphopenic hosts by CD4+ CD25+ regulatory T cells is antigen-specific and requires IL-10 and TGF-beta. J Immunol 2005;175:4283-4291.

25 Sanchez-Fueyo A, Sandner S, Habicht A, Mariat C, Kenny J, Degauque N, Zheng XX, Strom TB, Turka LA, Sayegh MH: Specificity of CD4+CD25+ regulatory T cell function in alloimmunity. J Immunol 2006;176:329334.

26 Battaglia M, Gregori S, Bacchetta R, Roncarolo MG: Tr1 cells: from discovery to their clinical application. Semin Immunol 2006;18:120-127.

27 Zhang X, Huang H, Yuan J, Sun D, Hou WS, Gordon J, Xiang J: CD4-8- dendritic cells prime CD4+ T regulatory 1 cells to suppress antitumor immunity. J Immunol 2005;175:2931-2937. 


\section{Cellular Physiology Cell Physiol Biochem 2017;43:353-366 \begin{tabular}{ll|l} 
DOI: 10.1159/000480415 & O 2017 The Author(s). Published by S. Karger AG, Basel \\
www.karger.com/cpb
\end{tabular} \\ Wan et al.: Type 1 T Regulatory Cells Induce Transplant-Tolerance}

28 Thornton AM, Shevach EM: CD4+CD25+ immunoregulatory T cells suppress polyclonal T cell activation in vitro by inhibiting interleukin 2 production. J Exp Med 1998;188:287-296.

-29 Trzonkowski P, Szmit E, Mysliwska J, Dobyszuk A, Mysliwski A: CD4+CD25+ T regulatory cells inhibit cytotoxic activity of T CD8+ and NK lymphocytes in the direct cell-to-cell interaction. Clin Immunol 2004;112:258-267.

-30 Jonuleit H, Schmitt E, Kakirman H, Stassen M, Knop J, Enk AH: Infectious tolerance: human CD25(+) regulatory T cells convey suppressor activity to conventional CD4(+) T helper cells. J Exp Med 2002;196:255-260.

-31 Vanasek TL, Nandiwada SL, Jenkins MK, Mueller DL: CD25+Foxp3+ regulatory T cells facilitate CD4+ T cell clonal anergy induction during the recovery from lymphopenia. J Immunol 2006;176:5880-5889.

32 Qiao M, Thornton AM, Shevach EM: CD4+ CD25+ [corrected] regulatory T cells render naive CD4+ CD25- T cells anergic and suppressive. Immunology 2007;120:447-455.

33 Cederbom L, Hall H, Ivars F: CD4+CD25+ regulatory T cells down-regulate co-stimulatory molecules on antigen-presenting cells. Eur J Immunol 2000;30:1538-1543.

-34 Munn DH, Sharma MD, Lee JR, Jhaver KG, Johnson TS, Keskin DB, Marshall B, Chandler P, Antonia SJ, Burgess R, Slingluff CL, Jr., Mellor AL: Potential regulatory function of human dendritic cells expressing indoleamine 2, 3-dioxygenase. Science 2002;297:1867-1870.

-35 Mosser DM, Zhang X: Interleukin-10: new perspectives on an old cytokine. Immunol Rev 2008;226:205218.

36 Groux H, Bigler M, de Vries JE, Roncarolo MG: Interleukin-10 induces a long-term antigen-specific anergic state in human CD4+ T cells. J Exp Med 1996;184:19-29.

-37 Groux H, O'Garra A, Bigler M, Rouleau M, Antonenko S, de Vries JE, Roncarolo MG: A CD4+ T-cell subset inhibits antigen-specific T-cell responses and prevents colitis. Nature 1997;389:737-742.

-38 Roncarolo MG, Gregori S, Battaglia M, Bacchetta R, Fleischhauer K, Levings MK: Interleukin-10-secreting type 1 regulatory T cells in rodents and humans. Immunol Rev 2006;212:28-50.

39 Thornton AM, Shevach EM: Suppressor effector function of CD4+CD25+ immunoregulatory T cells is antigen nonspecific. J Immunol 2000;164:183-190.

40 Yamazaki S, Iyoda T, Tarbell K, Olson K, Velinzon K, Inaba K, Steinman RM: Direct expansion of functional CD25+ CD4+ regulatory T cells by antigen-processing dendritic cells. J Exp Med 2003;198:235-247.

41 Sagoo P, Ali N, Garg G, Nestle FO, Lechler RI, Lombardi G: Human regulatory T cells with alloantigen specificity are more potent inhibitors of alloimmune skin graft damage than polyclonal regulatory T cells. Sci Transl Med 2011;3:83ra42.

42 Putnam AL, Safinia N, Medvec A, Laszkowska M, Wray M, Mintz MA, Trotta E, Szot GL, Liu W, Lares A, Lee K, Laing A, Lechler RI, Riley JL, Bluestone JA, Lombardi G, Tang Q: Clinical grade manufacturing of human alloantigen-reactive regulatory T cells for use in transplantation. Am J Transplant 2013;13:3010-3020. 